Halim, E. H., Mustika, G., Sari, R. N., Anugerah, R., \& Mohd-Sanusi, Z. (2017).

Corporate governance practices and financial performance: The mediating effect

of risk management committee at manufacturing firms. Journal of International

Studies, 10(4), 272-289. doi:10.14254/2071-8330.2017/10-4/21

\title{
Corporate governance practices and financial performance: The mediating effect of risk management committee at manufacturing firms
}

\section{Edyanus Herman Halim}

Department of Management, Faculty of Economics, Universitas Riau

Indonesia

edyanus1963@gmail.com

\section{Gita Mustika}

Department of Accounting, Faculty of Economics, Universitas Riau

Indonesia

gitamustika20@yahoo.co.id

\section{Ria Nelly Sari}

Department of Accounting, Faculty of Economics, Universitas Riau

Indonesia

ria.nellysari@lecturer.unri.ac.id

\section{Rita Anugerah}

Department of Accounting, Faculty of Economics, Universitas Riau

Indonesia

Rita.anugerab@lecturer.unri.ac.id

\section{Zuraidah Mohd-Sanusi}

Accounting Research Institute, Universiti Teknologi MARA

Malaysia

zuraidahms@salam.uitm.edu.my

Abstract. This study attempts to examine the effect of the Risk Management Committee on firm performance, and the intervening effect of the Risk Management Committee on the relationship between Corporate Governance, Firm Size, Financial Reporting Risk, and Firm Performance. Using the purposive sampling method, 299 firms were selected as the sample. This study used secondary data obtained from the companies' annual reports, and the data was then analyze using SPSS, version 20.0. The results of this study indicate that the entire research hypothesis is accepted. This study found that the Risk 
governance, firm size, and financial reporting risk on firm performance. The existence of RMC would facilitate the company to control better the quality of financial reporting risks.

Keywords: corporate governance, firm size, financial reporting risk, risk management, firm performance.

JEL Classification: M12, M48, M34

\section{INTRODUCTION}

In a situation of environmental uncertainty and competitive rivalry, companies face various risks in the course of their maintaining and improving their own performance. In order to reduce the losses caused by risks, the latter must be properly managed using risk management. Failures in risk management will cause losses to a company, directly or indirectly, as a consequence of events/activities that pose a risk (risk event). Failure to retain and improve firm performance can be seen from several cases faced by companies in Indonesia. Economic reforms in Indonesia did not run in line with several large-scale businesses, including those with foreign investors' participation. Some companies that are nationally well-known such as Ford Motor Indonesia, Toshiba, Panasonic, and General Motor Indonesia started to fall one by one in 2016. The global economic downturn, the decreasing purchasing power, the inability to compete with similar products, and the declining production volume as a result of high production costs caused declining firm performance and ultimately led these companies to discontinue their operations and move out from Indonesia (Koran SINDO, 2016; Aprillatu, 2016). Consequently, in order to avoid the possibility of bankruptcy, companies should regard risk as one of the factors to be considered in planning and making business decisions. A company should be able to identify, monitor, and control its risks, and as such, it requires an enterprise risk management system.

An effective risk management system is seen to help company achieve its business objectives, enhance its financial reporting as well as safeguard its reputation (Subramaniam et al., 2009). Adequate supervision is needed so that risk management system established by the company can be run effectively. Therefore, some companies take the initiative to set up another committee, separate from the audit committee, to run supervision and risk management, namely the Risk Management Committee (RMC). RMC is one of the committees established by the board of commissioners, which has the task of supervising the implementation of risk management within a company. The Risk Management Committee can be defined as an independent oversight committee, separate from the audit committee, being specifically responsible for providing the learning of risk management system, developing supervisory functions of risk at the level of commissioners, and evaluating the risk reports (KPMG, 2001). Development of RMC in Indonesia has been increasing, especially after the release of some rules related to the establishment of RMC obligations. These regulations require from commercial banks and insurance companies to establish RMCs. Meanwhile, for the sectors other than banking and insurance, the establishment of RMC is still voluntary. Therefore, not all companies listed at national Stock Exchange have RMCs already introduced.

Firm performance could be enhanced if there is good management committee in place. The function of this committee is to oversee the financial reporting process and ensure that all relevant and material information are disclosed (Edogbanya \& Kamardin, 2015). The risk management committee in some of the affected companies was found to have been negligent in monitoring risk of the companies (Kashyap et al., 2008). This is why companies have separate risk management committees composed of directors with the required skills to monitor risks facing companies and ensure safeguards put in place to mitigate the risks are 
adequate to current situation. Thus, poor monitoring of risks within various companies led to some of the management taking high risk, and that resulted in significant losses for companies that affected their overall performance. Numerous studies worldwide prove there is a positive relationship between RMC and firm performance (Gordon, Loeb, \& Tseng, 2009; Zemzem \& Kacem, 2014; Hoyt \& Liebenberg, 2011).

Empirical studies also show that the establishment of RMC in companies is affected by coporate governance and risks related to financial reporting: (Subramaniam, 2009) study on Australian firms, (Kallamu, 2015) study on Malaysian firms, (Viljoen \& Coetsee, 2014) research on South African firms.

Companies audited by the Big Four audit firms tend to have greater pressure to form a RMC, since the latter is seen as additional support when the auditor is assessing the internal risk monitoring system. Auditors prefer to minimize the risk of reputation loss by avoiding audit failure (Subramaniam et al., 2009). In addition, audit committees also support the RMC formation since they are aware of the risks faced by the company. The Audit Committee members not only supervise the process of reporting accounting and finances issues with certain financial risks but also other risks such as operational risk, strategic risk, and externality risk. Therefore, after the implementation of RMC, the process of controling risks can be run effectively so that company's goals can be achieved. RMC formation is also influenced by the size of the board of commissioners (Carson, 2002; Chen et al., 2009). Larger board will facilitate the exchange of expertise, information, and thoughts more widely, so it will be easier to find the right resources in the board of commissioners to be allocated to RMC. Frequency of board meetings also affects the RMC availability: frequency of board meetings potentially improves communication between directors and internal control managers (including those in RMC), thus making the board more effective in its oversight duties (Raghunandan \& Rama, 2007).

RMC is also influenced by various characteristics of the company, including the financial reporting risks (Chen et al., 2009; Sambera \& Meiranto, 2013). Organizations are increasingly faced with a variety of risks including financial, operational, reputation, regulatory, and information risks (KPMG, 2001); therefore, company should have RMC to minimize such risks. Financial reporting risks of companies are closely related to agency conflicts that could potentially occur, namely, those related to earnings' retention. Earnings retention is a situation where management tends to maintain the stability of a company, which aims to show good performance. It is strongly associated with the level of receivables and high inventories, thus, at the high level of receivables and inventories, companies tend to form a RMC as a supporting system for its monitoring mechanism (Sambera \& Meiranto, 2013).

The oversight of company's risk management process will increase by having a RMC. This is expected to encourage the achievement of effective risk management so that risk can be anticipated and managed for the purpose of increasing company's value. Increasing the value of a company is one reflection of its increased performance (Badriyah et al., 2015). This is also supported by Kaplan (2008) who stated that companies need to know how to measure risk and appoint managers who are responsible for risk management and have a risk committee, because company's performance is also affected by risk management factors.

Past studies have explored some of the factors that affect the existence of a RMC and firm performance such as corporate governance and firm characteristics, but their findings are inconsistent. Based on the discussion above, our study has been carried out with several purposes. Firstly, to analyse the effect of RMC on firm performance. Secondly, to analyse the role of RMC as an intervening variable mediating the relationship between corporate governance (such as auditor reputation, independence of audit committee, board size, and frequency of board meetings) and firm perfomance. Thirdly, to prove the role of RMC as an intervening variable that mediates the relationship between firm size and firm performance. Fourthly, to analyse the role of RMC as an intervening variable mediating the relationship between the risk of financial reporting and firm performance. 


\section{LITERATURE REVIEW}

\subsection{Agency Theory and Firm Performance}

Based on the agency theory, the principal or agent is assumed to be a rational person and purely motivated by personal interests. This situation leads to a conflict of interest between the principal and the agent. Principals can use two ways to restrain the actions of agents that are not in accordance with their interests: firstly, by monitoring the agent's behaviour by adopting auditing practices and other governance mechanisms that align the agent's interest with that of the principal's; and secondly, by providing attractive employment incentives to the agent and setting up reward structures that encourage the agent to act in the principal's best interests (Jensen \& Meckling 1976; Subramaniam et al., 2009). Previous research on corporate governance often uses the agency theory as a theoretical basis, in particular the existence of the committees. This is due to the importance of the monitoring aspects of good corporate governance. From the perspective of the agency theory, there are two common management oversight mechanisms; internal supervision and external supervision. Internal oversight mechanism is exercised by the board of commissioners and committees (Firth \& Rui, 2007; Chen et al., 2009), while the external oversight mechanisms are exercised by external auditors (Subramaniam et al., 2009). The committee formed by the board of commissioners is an application of effective corporate governance mechanisms to address the agency problem (Cai et al., 2008). Usually, that committee is predicted to exist in a situation where the agency cost tends to be high, for example, in the situation of high leverage and large sized companies (Subramaniam et al., 2009; Chen et al., 2009).

Firm performance is an important concept related to how financial resources that belong to the company are used appropriately to achieve the goals or objectives of the company (Yasser et al., 2011). Firm performance can be measured in two ways, accounting measures and capital market-based indicators. Performance measurement, which is based on accounting indicators are measured using financial ratios, while the capital market indicators are measured using calculations and information from the capital market. Performance measurement can improve productivity and quality, create a competitive edge, recognize the performance gap, and gain control over the agency problem between managers and shareholders (Saeidi et al., 2014).

\subsection{Risk Management Committee (RMC)}

RMC became popular as a supervisory mechanism of risk, which is important for the company (Subramaniam et al., 2009). This is further reinforced by a KPMG (2005) survey on Australian companies, which states that more than half of the respondents (54\%) had RMC, of which $70 \%$ were members of the audit committee. According to Subramaniam et al. (2009), the general area of the duties and authority of RMC are: First, to consider the organization's risk management strategy; Second, to evaluate the organization's risk management operations; Third, to assess the organization's financial reporting; and fourth, to ensure that the organization meets applicable laws and regulations in practice. In its establishment, the RMC could be incorporated with the audit committee or it could be separate and independent.

A separate committee that specifically focuses on risk issues (RMC), is considered to be an effective mechanism in support of the board of directors to fulfill their responsibilities in the task of monitoring risk and internal control management (Subramaniam et al., 2009). RMC that is separate from the audit committee will be able to devote more time and effort to incorporate some risks faced throughout the company and to evaluate the related overall control (Subramaniam et al., 2009). In addition, the RMC that is separate from the audit commitee also allows commissioners to understand the risk profile of the companies in depth (Bates \& Leclerc, 2009). RMC development in Indonesia has been increasing, especially after the release of 
some of the rules related to the establishment of RMC obligations. The regulations include Bank Indonesia Regulation Number 8/4 / PBI / 2006 regarding the implementation of GCG for Commercial Banks that requires commercial banks to form a RMC.

\subsection{Hypothesis Development}

\subsubsection{RMC and Firm Performance}

Firm performance should be maintained and improved continuously to attract investors and to maintain good relationships with stakeholders. Achievement of high firm performance also contains high risk, therefore, awareness on minimizing these risks is needed. Risk management is a way to manage risks that may affect the achievement of the firm's performance. In 2004, COSO issued the Enterprise Risk Management (ERM) - Integrated Framework that describes the essential components, principles, and concepts of the enterprise risk management for the entire organization regardless of size. Companies that implement the ERM can identify the risks contained in the business operations, evaluate how resources can be allocated to improve capital efficiency, prevent duplication of processes, and reduce the cost of risk management (Saeidi et al., 2014). To be effective, the ERM requires an adequate oversight, thus leading to the setting up of the RMC by the company's commissioner. RMC is the strength of a company enabling it to achieve its business objectives and to improve the quality of financial reporting as a safeguard of the company's reputation, and ultimately improve the company's performance. Since the RMC is responsible for inspecting, monitoring, and assessing the principles, policies, strategies, processes, and risk management control, this will generate a better risk management process, so that the risks that the company faces can be reduced and even prevented and ultimately influence the improvement of firm performance. Based on the framework above, then the hypothesis is:

H1: The existence of RMC affects firm performance.

The research model are developed and depicted in Figure 1 as "The Direct effects model".

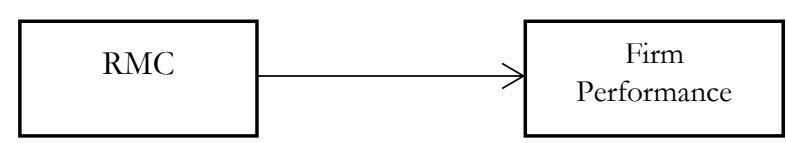

Figure 1. The direct effects model

\subsubsection{Auditor Reputation, RMC, and Firm Performance}

Auditor reputation reflects the reputation of a company's external auditor. Auditors who are members of the Big-Four accounting firms are considered likely to provide a good quality of audit and to have a good reputation and expertise to identify enterprise risks that may occur. The Big-Four accounting firms can provide guidance on good corporate governance practices, assist internal auditors in evaluating and improving the effectiveness of risk management so that they can improve the quality of risk assessment and supervision of the company (Andarini \& Januarti, 2012). All those activities might be motivated by the desire to maintain the quality of audit and to protect their reputation. Therefore, companies that use the Big-Four audit services will have more pressure to form the RMC compared to companies that use non Big-Four audit services. Existence of the RMC gives additional support when the auditor is assessing the internal risk monitoring system, as auditors prefer to minimize reputation losses of audit failure (Subramaniam et al., 
2009). The Risk Management Committee is more focused on overseeing risk management policies and procedures thereby improving the quality of risk assessment and monitoring companies. This statement is also supported by research conducted by Yatim (2009) which states that companies whose financial statements are audited by the Big-Four auditors tend to form the RMC. Forming the Risk Management Committee will also affect the company's overall performance, because this committee is responsible for inspecting, monitoring, and assessing the principles, policies, strategy management, control process, and risks that will result in good risk management and ultimately improve the overall company's performance. Therefore, the auditor's reputation can improve the company's performance through the presence and role of the Risk Management Committee.

\subsubsection{Independency of the Audit Committee, RMC, and Firm Performance}

The main requirement of the audit committee is the independence. The independence of the audit committee aims to maintain the integrity and objective view in the report as well as in the preparation of the recommendations made by the Audit Committee. The Audit Committee as an independent member is considered capable of providing an independent opinion, more objective and more able to offer criticism in relation to the policies conducted by the management (Porter \& Gendall, 1998). Thus, the Audit Committee that has more independent members will provide good monitoring of management policies, including risk-taking activities. In addition, independent members have an interest to enhance their reputation as good observers (Yatim, 2009). Therefore, an independent member will support the establishment of the RMC to help maximize the function of monitoring, particularly in risk management. Yatim (2009) asserted that the independence of the Audit Committee had a positive and significant relationship with the formation of the company's RMC. An independent audit committee will be able to perform their duties optimally and automatically improve the management of the company. The Audit Committee will support the RMC, since the RMC is aware of the risks that the company is facing. The Audit Committee members do not only supervise the process of reporting the accounting and finances that become a financial risk to the company but many types of other risks such as operational risk, strategic risk, and risk externalities are also supervised. The existence of the audit committee as one of the mechanisms of good corporate governance (GCG) will encourage the establishment of a risk management committee so that a company's risks can be well-managed and eventually improve the company's performance.

\subsubsection{Size of the Board of Commissioners, RMC, and Firm Performance}

The establishment of the RMC might be related to the size of the board. Large board size tends to be a great resource for the Board of Commissioners (Subramaniam et al., 2009). Larger board size will give strength in the oversight function performed by the Board of Commissioners. It has been stated by Subramaniam et al. (2009) that the committees established by the Board of Commissioners such as the Audit Committee, the Nomination and Remuneration Committee exist when the agency cost is high, such as high leverage as well as the complexity and large size of the company. This might be an encouragement to the BOC to form the RMC. Therefore, the larger size board is expected to help the performance of the Board in implementing risk management and overseeing the performance of the agent so that the agent does not infringe the authority that has been given by the principal. A larger board size will provide greater opportunity to find members with the necessary skills to coordinate and be involved in the committees formed by the Board of Commissioners designated for risk management (Subramaniam et al., 2009). Consequently, it will be easier for the BOC to form the RMC with a large number of human resources so that it would make the BOC more likely to establish the RMC separate from the Audit Committee. RMC will increase risk management effectiveness through supervision. RMC will be able to identify, monitor, 
control, and minimize the risks faced by the company and it will enhance the firm performance. According to Boniface and Ibe (2012) risk management is an important part that affects the company's revenue growth and profitability in the future. Revenue growth and profitability is one of the achievements of the company's performance. Based on the description above, it can be concluded that the size of the company will affect the company's performance through risk management committee.

\subsubsection{Frequency of board meetings, RMC, and Firm Performance}

According to Cotter et al. (1998), the frequency of board meetings is an essential resource for creating effectiveness of the Board of Commissioners. BOC as a centre for implementing internal control has the role of the supervisory function and must be continuously aware of all information related to the company. Therefore, the BOC will conduct meetings very often. The frequency of board meetings will potentially improve communication between directors and internal control functions (such as RMC) and make the board more effective in its oversight duties. The frequency of board meetings makes a board more active (Raghunandan \& Rama, 2007). Fewer meetings means lesser information for the BOC about potential risks that the company could be facing in the future. Therefore, more frequent BOC meetings will increase information and knowledge about the condition of the company, especially the company's risk monitoring and risk management that will affect the implementation of the supervisory function that supports the establishment of the RMC. Yatim (2010) found that the frequency of board meetings had a positive effect with the presence of a RMC. Higher frequency of meetings is associated with a decreased incidence of financial reporting issues and improved quality of external audits. Financial reporting incidents would reduce if the BOC acquires quality information from the management about risks with no information asymmetry. This will encourage companies to organize a committee that oversees the risk to help the supervision of the Commissioners in obtaining the information that is relevant, accurate, and on time. Risk Management Committee may lead the company to improve firm performance, since RMC assists companies in setting the strategy and to revise the strategy to be relevant to the evolving situation. Thus, it can be inferred that the frequency of board meetings could affect the company's performance through the existence of a risk management committee.

\subsubsection{Financial Reporting Risk, RMC, and Firm Performance}

Information asymmetry occurs when managers are in a position with more information about the company than the shareholders. Sometimes, financial reporting may lead to information asymmetry for the investors. The financial statements have many assumptions, assessment, and selection of calculation methods that can be used to make the management flexible enough to manipulate the financial statements. Thus, the financial reporting risks become higher and require stronger monitoring to oversee the management such as establishing the Risk Management Committee (RMC), which is separate from the Audit Committee. Sambera and Meiranto (2013) stated that the financial reporting risk is highly correlated with the agency conflict that could potentially occur, which is called 'earnings retention'. Earning retention is a situation where the management tends to maintain a stable level of the company, which aims to show good management performance. It is strongly associated with the high level of receivables and inventories. With a high level of receivables and inventories, companies tend to form the RMC as a form of monitoring the management. Therefore, the existence of RMC would facilitate the company to control the quality of financial reporting risks better (Subramaniam et al., 2009). Management risk that is undertaken by the RMC will reduce the costs incurred due to agency conflict. Moreover, RMC can also reduce financial difficulties because the committee would have better knowledge about critical risks and the potential impact on their 
company. Thus, the RMC will increase stakeholder value, competitive advantage, and the organization's ability to achieve goals that will ultimately affect the performance of the company (Saedi et al., 2014).

Figure 2 below illustrates the relationships among corporate governance such as auditor reputation, independency of the audit committee, size of the board of commissioners, frequency of board meetings, firm size, and financial reporting risks as the independent variables; Risk Management Committe as the mediating variable; and Firm performance as the dependent variable.

Based on the theoretical background, following hypothesis are proposed to test propositions of mediating effects Risk Management Committee (RMC) :

H2: Auditor reputation affects firm performance through the existence of the RMC

H3: The Independency of the audit committee affects firm performance through the existence of the $\mathrm{RMC}$

H4: The size of the board of commissioners affects firm performance through the existence of the RMC

H5: The frequency of board meetings affects firm performance through the existence of the RMC.

H6: The risks of financial reporting affect firm performance through the existence of the RMC

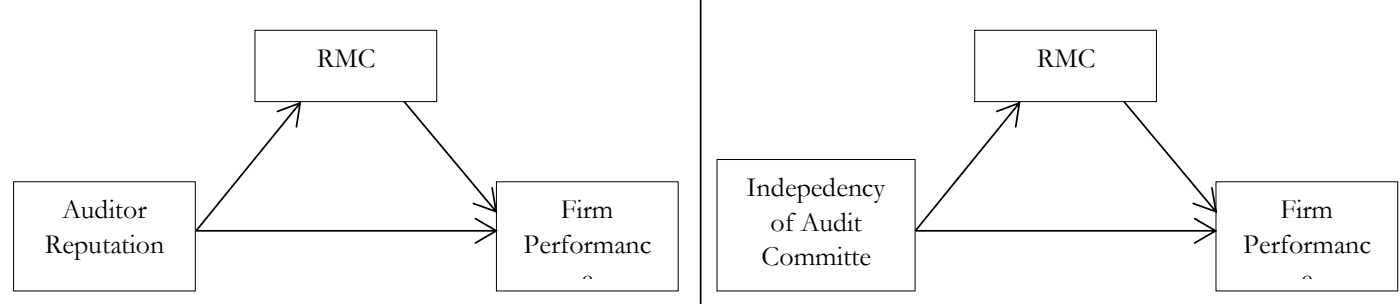

Hypothesis 2

Hypothesis 3

Size of board commissione

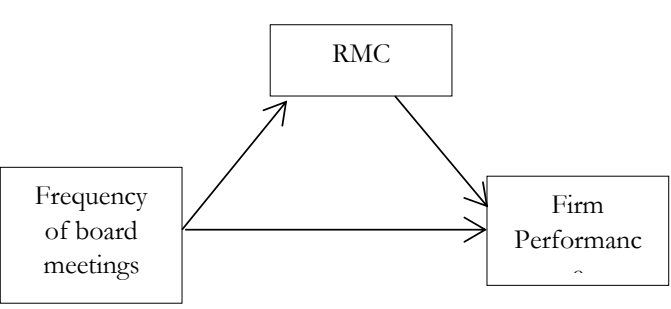

Hypothesis 5

Figure 2 . The mediating effects models 


\section{METHODOLOGY}

\subsection{Population, sample, and data collection}

The population in this study is the non-financial companies listed in the Indonesia Stock Exchange (ISE) for 2014 financial year. The purposive sampling is used with several criteria, namely, non-financial company, listed on the ISE, published annual reports in 2013, and has complete information. The data in this study was collected from annual reports taken from the official website of the Indonesia Stock Exchange, www.idx.co.id.

\subsection{Variables and masurement}

\subsubsection{Firm Performance}

Firm performance is defined as a concept that explains the success of a company or a reflection of the fulfillment of the objectives of a company (Saeidi et al., 2014). One of the classical measures of performance is the return on assets (ROA), usually calculated as earnings before interest and taxes (EBIT) over total assets (Machek, 2016). We adopt this approach in this article as well and measure the dependent variable firm performance using return on assets.

\subsubsection{The existence of the RMC}

Risk management committee is defined as the Board of Commissioners that assists the implementation of supervisory duties in the field of enterprise risk monitoring. This variable is a dichotomous variable; 1 for the company which reports a RMC in its annual report (either a special risk committee or included in the audit committee) and 0 for the company that does not report a RMC in its annual report (Subramaniam et al., 2009).

\subsubsection{Auditor Reputation}

Auditor Reputation is defined as Big-Four and non Big-Four audit firms that perform external audit in the companies. Reputation of auditor is a dichotomous variable where companies that are audited by the Big-Four accounting firm as the external auditor is given a value of one (1) and a value of zero (0) is given to the company that is audited by a non-Big-Four accounting firm ( Subramaniam et al., 2009).

\subsubsection{Independency of the Audit Committee}

The audit committee consists of a selected number of members from the board of commissioners who have some responsibilities including helping auditors remain independent from the management. Most audit committees are made up of three to five or sometimes as many as seven members who are not a part of the company's management (Arens et al., 2008). In this study, the independence of the audit committee is measured by using the ratio of independent audit committee members with the total number of members of the audit committee (Yatim, 2009) .

\subsubsection{The size of the Board of Commissioners}

Board size is measured by the total number of commissioners on the board (Subramaniam et al., 2009). 


\subsubsection{Frequency of Board Meetings}

The effectiveness of the board can be influenced by the frequency of meetings. A high frequency of meetings can produce better monitoring. In this study, the frequency of board meetings is measured by the number of meetings held during the year (Yatim, 2009).

\subsubsection{Financial Reporting Risks}

The greatest proportion of high value assets of companies comes from trade receivables and inventories and is likely to have higher financial reporting risks. This is because of the high level of uncertainty in the accounting data (Koroses \& Horvat, 2005 in Subramaniam et al., 2009). Financial reporting risk variables are measured by dividing the total amount of receivables and inventories with the total assets of the company (Subramaniam et al., 2009) .

\subsubsection{Control variable: Firm size}

Firm size is an indicator that can reflect the condition or characteristic of an organization or company and there are several parameters used to determine the size of a large or small company (Astriani, 2014). Firm size is measured by total assets of the company (Subramaniam et al., 2009). For statistical analysis purposes, firm size is transformed into a log of total assets.

\section{EMPIRICAL RESULTS AND DISCUSSION}

\subsection{Descriptive statistics}

299 non-financial companies met the sampling criteria. The descriptive statistics of the variables are presented in Table 1.

Table 1

Descriptive Statistics $(\mathrm{N}=299)$

\begin{tabular}{|c|c|c|c|c|}
\hline Measurement of Variables & Minimum & Maximum & Mean & Std. Deviation \\
\hline $\mathrm{ROA}$ & -0.50 & 0.63 & 0.0689 & 0.12265 \\
\hline $\begin{array}{l}\text { Number of the Board of } \\
\text { Commissioners }\end{array}$ & 2.00 & 10.00 & 4.1271 & 1.66000 \\
\hline $\begin{array}{l}\text { Frequency of Board } \\
\text { Meetings }\end{array}$ & 1.00 & 13.00 & 4.3344 & 2.63594 \\
\hline REC\&INV/ASSET & 0.00 & 1.33 & 0.2506 & 0.21890 \\
\hline $\begin{array}{l}\text { Ratio of Independent } \\
\text { members with total Audit } \\
\text { Committee }\end{array}$ & 33.33 & 100.00 & 65.6355 & 8.47340 \\
\hline Log Total Assets & 9.27 & 13.93 & 12.2028 & 0.75763 \\
\hline $\begin{array}{l}\text { The existence of the RMC } \\
\text { Has RMC } \\
\text { Doesn't Have RMC }\end{array}$ & \multicolumn{4}{|c|}{$\begin{array}{l}46.15 \% \\
53.85 \%\end{array}$} \\
\hline $\begin{array}{l}\text { Auditor Reputation } \\
\text { Big-Four Audit Firm } \\
\text { Non Big-Four Audit Firm }\end{array}$ & \multicolumn{4}{|c|}{$\begin{array}{l}32.78 \% \\
67.22 \%\end{array}$} \\
\hline
\end{tabular}


On average, firm performance of the companies being studied, which is proxied by the ROA, is 0.0689 . On average, non-financial companies have at least 2 commissioners, and a maximum of 10 commissioners. The average board meeting is four times a year, with a minimum of 1 and a maximum of 13 meetings. On average, the ratio independent members of the audit committee is $65.63 \%$.. $46.15 \%$ of the companies have a RMC $(n=138)$ and 32.78 percent of the companies are audited by the Big-Four Audit Firms $(n=98)$ with an average financial reporting risks of 0.25 .

\subsection{Regression Analysis}

Normality test aimed at confirming that all the used data is normally distributed. Normality test using Kolmogorov-Smirnov Test. The variables' values are $>0,05$ and it is assumed that all variables are normally distributed and clustered in the centre. Table 2 present the result of the normality test..

Table 2

Normality Test

\begin{tabular}{|l|l|c|}
\hline \multicolumn{2}{|l|}{} & Unstandardized Residual \\
\hline N & \multicolumn{1}{|c|}{299} \\
\hline \multirow{2}{*}{ Normal Parametersa,b } & Mean & 0 E-7 \\
\cline { 2 - 3 } & Std. Deviation &, 14709035 \\
\hline \multirow{3}{*}{ Most Extreme Differences } & Absolute &, 066 \\
\cline { 2 - 3 } & Positive &, 066 \\
\cline { 2 - 3 } & Negative &,- 033 \\
\hline Kolmogorov-Smirnov Z & 1,138 \\
\hline Asymp. Sig. (2-tailed) &, 150 \\
\hline
\end{tabular}

a. Test distribution is Normal.

b. Calculated from data.

Multicollonearity test aims to test whether in the regression model found the existence of correlation between independent variables. Table 3 below shows the summarized results of the multicollonearity test. VIF values for all independent variables are $<10$ and its tolerance values are $>0.10$. It can be concluded that the regression model is free from multicolinearity.

Table 3

Multicollonearity Test

\begin{tabular}{|l|c|c|}
\hline \multirow{2}{*}{\multicolumn{1}{|c|}{ Independent Variables }} & Tolerance & VIF \\
\cline { 2 - 3 } & 0,676 & 1,479 \\
\hline Firm Size & 0,657 & 1,522 \\
\hline The size of the bord of commissioners & 0,826 & 1,21 \\
\hline Frequency of Board Meeting & 0,942 & 1,061 \\
\hline Financial Reporting Risk & 0,869 & 1,15 \\
\hline Auditor Reputation & 0,91 & 1,099 \\
\hline Independency of the Audit Committee & 0,74 & 1,351 \\
\hline RMC & & \\
\hline
\end{tabular}


A good regression model is no heterocedasticity. The method used to detect heteroscedasticity in this study is Spearman's Rho test. Result of spearman's rho test show in Table 4. It can be seen significant value of all variables greater than 0,05 and can be concluded that there is no heterocedasticity in the regression model.

Table 4

Heteroscedasticity Test

\begin{tabular}{|c|c|c|c|}
\hline & & & Unstandardized Residual \\
\hline \multirow{21}{*}{ Spearman's rho } & \multirow{3}{*}{$\begin{array}{l}\text { The size of the Board of } \\
\text { commissioners }\end{array}$} & Correlation Coefficient & $-0,002$ \\
\hline & & Sig. (2-tailed) & 0,979 \\
\hline & & $\mathrm{N}$ & 299 \\
\hline & \multirow{3}{*}{$\begin{array}{c}\text { Fequency of Board } \\
\text { Meetings }\end{array}$} & Correlation Coefficient & 0,017 \\
\hline & & Sig. (2-tailed) & 0,768 \\
\hline & & $\mathrm{N}$ & 299 \\
\hline & \multirow{3}{*}{ Financial Reporting Risk } & Correlation Coefficient & 0,012 \\
\hline & & Sig. (2-tailed) & 0,831 \\
\hline & & $\mathrm{N}$ & 299 \\
\hline & \multirow{3}{*}{ Auditor Reputation } & Correlation Coefficient & \\
\hline & & Sig. (2-tailed) & 0,822 \\
\hline & & $\mathrm{N}$ & 299 \\
\hline & \multirow{3}{*}{$\begin{array}{l}\text { Indepedency of the Audit } \\
\text { Committee }\end{array}$} & Correlation Coefficient & $-0,002$ \\
\hline & & Sig. (2-tailed) & 0,972 \\
\hline & & $\mathrm{N}$ & 299 \\
\hline & \multirow{3}{*}{ Firm Size } & Correlation Coefficient & 0,044 \\
\hline & & Sig. (2-tailed) & 0,444 \\
\hline & & $\mathrm{N}$ & 299 \\
\hline & \multirow{3}{*}{ RMC } & Correlation Coefficient & $-0,008$ \\
\hline & & Sig. (2-tailed) & 0,887 \\
\hline & & $\mathrm{N}$ & 299 \\
\hline
\end{tabular}

The adjusted $\mathrm{R}$ squared for this study is 0.201 , which indicates that $20.1 \%$ of the variation in the Financial Performance can be explained by the interaction of corporate governance practices, firm size and Risk of finacial reporting.

Table 5

T-test

\begin{tabular}{|c|c|c|c|c|c|c|}
\hline & \multirow[t]{2}{*}{ Model } & \multicolumn{2}{|c|}{ Unstandardized Coefficients } & \multirow{2}{*}{$\begin{array}{c}\text { Standardized } \\
\text { Coefficients }\end{array}$} & \multirow[t]{2}{*}{$\mathbf{t}$} & \multirow[t]{2}{*}{ Sig. } \\
\hline & & $\mathbf{B}$ & Std. Error & & & \\
\hline \multirow{2}{*}{1} & (Constant) & ,194 & ,013 & & 15,457 &, 000 \\
\hline & $\mathrm{RMC}$ & 085 & ,018 & ,257 & 4,583 & ,000 \\
\hline
\end{tabular}


T-test is done to know how big influence of independent variable to dependent variable partially. The benchmark used is to compare the significant value generated with alpha 0.05 . Table 5 presents the result of the T-test. Data in this study proves that the existence of the RMC affects firm performance $(\beta=0.085$, $\varrho=0,000)$. This indicates that the existence of the RMC as a part of the oversight function over the implementation of ERM has an effect on improving firm performance. Therefore, $\mathrm{H} 1$ is accepted.

Table 6 presents the indirect effect and the role of RMC as an intervening variable. To test the hypothesis of the indirect relationships, and to test the role of the RMC as an intervening variable, a series of tests as suggested by Frazier et al. (2004) has been done. In the first step, all independent variables have been proven to influence the performance of the company, thus the first criterion for testing the mediating variables has been met. In the second step, all independent variables have been proven to influence the $\mathrm{RMC}$ thus the second criterion to test the intervening variables has been met. In the third step, the RMC is shown to have an influence on the performance of the company, thus the third criterion has been met. In the fourth step, the value of $\beta$ that shows the influence of the independent variables on the performance of the company after the inclusion of the RMC variable becomes smaller, thus, RMC acts as a partial mediation. Therefore, H2, H3, H4, and $\mathrm{H} 5$ are supported. In addition, financial reporting risk also affects firm performance through the existence of RMC. It is concluded that corporate governance such as auditor reputation, independency of the audit committee, board size, frequency of board meeting and financial reporting risk would affect the formation and existence of the RMC in a company. The establishment of the RMC would improve the effectivenes of the ERM through supervision so that the risk faced by the company can be minimized, which in turn will enhance the firm performance.

Table 6

Multiple Regression Analysis

\begin{tabular}{|c|c|c|c|c|c|}
\hline $\begin{array}{l}\text { Independent } \\
\text { Variables }\end{array}$ & $\begin{array}{c}\text { Independent } \\
\text { Variable }> \\
\text { Dependent } \\
\text { Variable }\end{array}$ & $\begin{array}{c}\text { Independent } \\
\text { Variable }> \\
\text { The existence } \\
\text { of RMC }\end{array}$ & $\begin{array}{c}\text { The existence } \\
\text { of RMC }> \\
\text { Firm } \\
\text { Performance }\end{array}$ & $\begin{array}{c}\text { Independent } \\
\text { Variable, } \\
\text { RMC > Firm } \\
\text { Performance }\end{array}$ & Conclusion \\
\hline & First Step & Second Step & Third Step & Fourth Step & \\
\hline $\begin{array}{l}\text { Auditor } \\
\text { Reputation }\end{array}$ & $\begin{array}{l}\beta=0.103 \\
\varrho=0.000\end{array}$ & $\begin{array}{l}\beta=0.239 \\
\varrho=0,000\end{array}$ & \multirow{5}{*}{$\begin{array}{l}\beta=0.085 \\
\varrho=0.000\end{array}$} & $\begin{array}{l}\beta=0.087 \\
\varrho=0,000\end{array}$ & $\mathrm{H} 2$ is accepted \\
\hline $\begin{array}{l}\text { Independency of } \\
\text { the Audit } \\
\text { Committee }\end{array}$ & $\begin{array}{l}\beta=0.057 \\
\varrho=0.001\end{array}$ & $\begin{array}{l}\beta=0.128 \\
\varrho=0.012\end{array}$ & & $\begin{array}{l}\beta=0.047 \\
\varrho=0.004\end{array}$ & $\mathrm{H} 3$ is accepted \\
\hline $\begin{array}{l}\text { The size of the } \\
\text { Board of } \\
\text { Commissioners }\end{array}$ & $\begin{array}{l}\beta=0.089 \\
\varrho=0.000\end{array}$ & $\begin{array}{l}\beta=0.505 \\
\varrho=0.000\end{array}$ & & $\begin{array}{l}\beta=0.055 \\
\varrho=0.030\end{array}$ & $\mathrm{H} 4$ is accepted \\
\hline $\begin{array}{l}\text { Frequency of } \\
\text { Board Meetings }\end{array}$ & $\begin{array}{l}\beta=0.051 \\
\varrho=0.001\end{array}$ & $\begin{array}{l}\beta=0.255 \\
\varrho=0.000\end{array}$ & & $\begin{array}{l}\beta=0.033 \\
\varrho=0.029\end{array}$ & H5 is accepted \\
\hline $\begin{array}{l}\text { Financial } \\
\text { Reporting Risks }\end{array}$ & $\begin{array}{l}\beta=0.175 \\
\varrho=0.000\end{array}$ & $\begin{array}{l}\beta=0.239 \\
\varrho=0.046\end{array}$ & & $\begin{array}{l}\beta=0.156 \\
\varrho=0.000\end{array}$ & H6 is accepted \\
\hline
\end{tabular}

\subsection{DICUSSION}

The main objective of this study is to examine the role of RISk Manajement Committe analyse the role of a Risk Management Committee as intervening variable between corporate governance, firm size, risk of financial reporting and corporate performance. Based objectives of the study, six hypotheses were developed. 
The first hypothesis predicted that the existence of RMC improve firm performance. Since risk is inherent in all business activities, it is important for the business to understand the risks it faces and to put adequate measures to prevent, reduce or deal with the risks (Krause, 2006). Monitoring of risks is necessary since excessive risks could make companies to sustain huge losses and also lead to problem for the whole financial system and the entire economy $(\mathrm{Ng}, 2013)$. This revelation is supported by Professor Kaplan (2008), companies need to know how to measure risk management and appoint managers responsible for risk management. Today the company has implemented risk management very seriously and has adopted several core principles of risk management. One such principle is to have a risk committee, which is a special committee that is responsible for overseeing and implementing risk management within the company. Having risk management committee as separate board committees saddled with specific aspect of the board functions enable the directors to concentrate and specialize on a specific area and devote more time to their work through improvement in attendance at board and committee meetings (Harrison, 1987). Therefore, having separate RMC will lead to better monitoring of risk which will reduce losses and enhance performance. H1 is supported. Evidence shows that there existence of RMC affects firm performance. Thus, consistent with Kallamu (2015).

The second hypothesis in this paper predicted Auditor reputation affect firm performance throught the existence of the RMC. This is supported by the result of this study. Audit firms are generally able to influence their client's internal control systems by making post-audit recommendations on improving the design of such systems. Big Four audit firms have been found to encourage higher quality internal monitoring mechanisms among their clients than non-Big Four firms (Cohen et al.,2004). This push is seen to be motivated by the need to maintain audit quality and to protect their brand name. It is thus expected that there will be greater pressure among organisations with a Big Four firm organisations to establish a RMC than in firms with a non-Big Four. When the auditor is assessing the company's internal risk monitoring system, and identifying the company's risk, the existence of a risk management committee is seen as an additional support, which in turn is likely to minimise the loss of reputation through audit failure. Companies that use Big Four audit services will tend to form a Risk Management Committee, risk management committees focus more on overseeing risk management policies and procedures thereby enhancing the quality of risk assessment and monitoring of the company (Subramaniam et al. 2009). Establishing a corporate risk management committee will improve the effectiveness of corporate risk management through its oversight. Effective risk management will be able to recognize, monitor, control and minimize risks faced by companies that will ultimately affect the improvement of company performance.

The third hypothesis assume independent audit committee affect firm performance throught the existence of the RMC. this regression results support the hypothesis. The Audit Committee that has more independent members have an interest to enhance their reputation as good observers. This view is consistent with the agency perspective, in that, independent audit committees provide greater monitoring of managerial discretions including risk-taking activities by managers. Independent audit committee members are likely to view their service on an audit committee as a means of enhancing their reputational capital. The preservation of reputational capital serves as a motivation for higher quality monitoring. It is, therefore, expected that an independent audit committee provides effective monitoring and helps strengthen internal controls. Thus, consistent with a risk-based approach, an independent audit committee is likely to support the establishment of a risk management committee because it is beneficial and useful to audit committee, for instance, in reviewing the firm's risk assessment system.Thus, consistent with Yatim (2009). Independent member will support the establishment of the RMC to help maximize the function of monitoring, particularly in risk management. Yatim (2009) asserted that the independence of the Audit Committee had a positive and significant relationship with the formation of the company's RMC. An independent audit committee will be 
able to perform their duties optimally and automatically improve the management of the company. The Audit Committee will support the RMC, since the RMC is aware of the risks that the company is facing. The existence of the audit committee will encourage the establishment of a risk management committee so that a company's risks can be well-managed and eventually improve the company's performance.

The fourth hypothesis of this paper state size of boad of commissioners affect firm performance throught the existence of the RMC. In order to establish a Risk Management Committee, it is required that additional members of the board of commissioners be allocated to the established risk management committee. The size of a large board can be a great resource for the board of commissioners. With so many resources available, it will be easier for organizations to establish risk management committees. The exchange of information, skills, and thoughts will also occur more widely, so it will be easier to find the right resources within the board of commissioners to allocate in the tasks of the Risk Management Committee. The large number of boards also adds opportunities for exchanging information and skills to improve the quality of risk management implementation under the risk management committee. Thus, consistent with Subramaniam et al (2009). RMC will increase risk management effectiveness through supervision. RMC will be able to identify, monitor, control, and minimize the risks faced by the company and it will enhance the firm performance. According to Boniface and Ibe (2012) risk management is an important part that affects the company's revenue growth and profitability in the future. this regression results support the fourth hypothesis.

Hypothesis 5 predicted that frequency of board metings affect firm performance throught the existence of the RMC. Board meetings is appropriate given that frequent board meetings potentially allow for improved ommunication between directors and internal control function and enable the board of directors to be more effective in their oversight. In addition, frequent board meetings suggest a more active board (Raghunandan and Rama 2007). The intensity of board activities is likely to contribute to the effectiveness of its oversight function such as in matters concerning firm operations and investments. A board that demonstrates a greater diligence in discharging its oversight responsibilities is likely to enhance the level of oversight of the risk management activities. As such, it is expected that more frequent BOC meetings will increase information and knowledge about the condition of the company, especially the company's risk monitoring and risk management that will affect the implementation of the supervisory function that supports the establishment of the RMC. Therefore, similar to Yatim 2010. Risk Management Committee may lead the company to improve firm performance, since RMC assists companies in setting the strategy and to revise the strategy to be relevant to the evolving situation, this result supports hypothesis 5 .

The last hypothesis of the current research claimed that risk of financial reporting affect firm performance throught the existence of the RMC. The risk of financial reporting is shown by the ratio of the number of receivables and inventories to the total assets of the company. The higher the proportion of receivables and inventories within the company's assets the higher the risk of financial reporting. This is because the greater the amount of accounts receivable companies then large risk of bad debts. Similarly with inventory, the greater the amount of inventory the greater the obsolete inventory risk. The high proportion of receivables and inventories also carries the risk of errors in the assessment and the higher the calculation. So both of these will increase the risk of financial reporting faced by the company. To identify, monitor and control the risks facing the company related to the characteristics of the company, the company must implement an effective management system. An effective risk management system will be the company's strength that can minimize and control the risks facing the company so that it can achieve the goals and objectives of the company will ultimately improve the performance of the company. In order for the system established by the company to run effectively, required an adequate supervision. In order to exercise an adequate supervisory role on the implementation of the company's risk management, it is necessary to establish a responsible, specific committee, the risk management committee. The existence of RMC would 
facilitate the company to control the quality of financial reporting risks better (Subramaniam et al., 2009). RMC can reduce financial difficulties because the committee would have better knowledge about critical risks and the potential impact on their company. Thus, the RMC will increase stakeholder value, competitive advantage, and the organization's ability to achieve goals that will ultimately affect the performance of the company (Saedi et al., 2014).

\section{CONCLUSION}

The existence of RMC is a strength for the company that will help it to achieve business objectives. Auditor reputation, independency of the audit committee, board size, and frequency of board meetings support the company to set up RMC to assist companies in minimizing risk, so the company can assess and control the risks that exist and will ultimately improve company performance. In addition, large size company, which has a high risk of financial reporting, will also form RMC as a formation of management monitoring. The existence of RMC would facilitate the company to control the quality of financial reporting risks to be better, the establishment of RMC also aims to monitor, assess, control, and monitor risk of exploiting the possibilities that exist that will increase the company's revenue growth and profitability in the future. The present study provides The role of risk management committee as intervening variable, thus contributing to the literature in several ways. First, the findings of this study provide systematic empirical evidence on RMC in Indonesia companies where the adoption of RMC is still voluntary. The study clearly identifies that the existence of Risk Management Committee affect Firm Perfomance. Secondly, the present findings clearly highlight the role of a Risk Management Committee as intervening variable between corporate governance such as auditor reputation, the independence of the audit committee, board size, frequency of board meetings and firm perfomance. Last but not least, thirdly this study found that the risk of financial reporting affect firm performance through risk management committee. The results of this study indicate that the entire research hypothesis is accepted. The finding of this study has implication to the company to form RMC since it will contribute to the enhancement firm performance.

There are however several limitations of the study. This study used a 1 year observational data; future studies are expected to add years of observation in order to get better results. The second limitation of the study is that the data were collected from companies' annual reports. Thus, only firms that have reported having a RMC in the annual reports have been included in the study. It is possible that companies may use other structures for managing their risks and not call themselves a RMC. Unfortunately, there is limited information about companies' risk management structures in annual reports. Therefore, future studies may review the existence of alternate structures, and other research methods such as a questionnaire survey or interviews of board representatives may help to better understand the use of such alternate risk management structures in an organisation. Thirdly, the sample of the study is only 299 Indonesia firms listed on BEI. Thus, the generalisability of the results is limited. Future studies may extend their investigation to a larger sample, and also may do comparative study, studies could examine the impact of RMC on the performance companies in other country. This would assist in having more understanding about role of Risk Management Committee in each country. The fourthly limitation of the study is that the variables such as ROA in regression models may not be good proxies for firm performance. Future studies can also include different variables to be tested in determining the firm performance such as Return on Equity (ROE), Tobin-Q, Profit Margin (PM), Earnings Per Share (EPS), Divided Yield (DY), Return on Sales (ROS), Return on Investment (ROI), Market-to-book value (MTBV), Growth in Sales (GRO). These added variables are useful to gain a deeper understanding and to give detailed information and explanation that can provide additional monitoring mechanisms for external users such as investors and creditors in making decisions. 


\section{ACKNOWLEDGEMENT}

The authors are thankful to the Universitas Riau research grant for financial support to carry out this research.

\section{REFERENCES}

Andarini, P., \& Jumiarti, I. (2012). Hubungan karakteristik dewan komisaris dan perusahaan terhadap keberadaan komite manajemen risiko pada perusahaan go public di Indonesia. Jurnal Akuntansi dan Kenangan Indonesia, 9(1), 83-99.

Aprillatu, P. D. (2016, Februari 2). Tak hanya panasonic dan toshiba yang bangkrut di Indonesia. Retrieved from http://www.merdeka.com/uang/tak-hanya-panasonic-dan-toshiba-yang-bangkrut-di-indonesia.html

Arens A. A., Elder R. J., Beasley, M. S. (2008). Auditing dan Jasa Assurance (12th ed). (Herman Wibowo, Trans). Jakarta: Erlangga. (Original work published 2008).

Astriani, E. F. (2014). Pengaruh kepemilikan manajerial, leverage, profitabilitas, ukuran perusahaan dan investment opportunity set terhadap nilai perusahaan. Jurnal Akuntansi dan Bisnis, 2(1), 1-25

Badriyah, N., Sari, R. N., Basri, Y. M. (2015). The effect of corporate governance and firm characteristic on firm performance and risk management as an intervening variable. Procedia Economics and Finance, 31 (2015), 868-875.

Bates, E. W., \& Leclerc, R. J. (2009) Boards of Directors and Risk Committes. The Corporate Governance Adivisor, 17 (6), 16-20.

Boniface, U., \& Ibe, I. G. (2012). Enterprise risk management and performance of Nigeria's brewery industry. Developing Country Studies, 2(10), 60-67.

Cai J., Qian Y., Liu Y. (2008). Information asymmetry and corporate governance. Drexel College of Business Research Papers, No. 02, http://ssrn.com/abstract=1082589.

Carson, E. (2002). Factors associated with the development of board sub-committees. Corporate Governance: An International review, 10(1), 4-18. doi:10.1111/1467-8683.00263

Chen, L., Kilgore, A., \& Radich, R. (2009). Audit committees: voluntary formation by asx ntop 500. Managerial Auditing Journal, 24(5), 475-493.

Cotter, J., Shivdasani, A., \& Zenner, M, (1997). Do independent directors enhance target shareholder wealth during tender offers?. Journal of Financial Economics, 43, 195-218.

Edogbanya, A., \& Kamardin, H. (2015). Adoption of International Financial Reporting Standards in Nigeria: Concepts and Issues. Mediterranean Journal of Social Sciences, 6(3), doi:10.5901/mjss.2015.v6n3p206

Firth, M., Fung, P. M. Y., \& Rui, O. M. (2007). Ownership, two-tier board structure, and the informativeness of earnings-Evidence from China. Journal of Accounting and Public Policy, 26(4), 463-496.

Frazier, P. A., Tix, A. P., \& Barron, K. E. (2004). Testing moderator and mediator effects in counseling psychology research. Journal of Counseling Psychology, 51, 115-134.

Gordon, L., Loeb, M. P., \& Tseng, C.-Y. (2009). Enterprise risk management and firm performance: A contingency perspective. Journal of Accounting and Public Policy, 28(4), 301-327. doi:10.1016/j.jaccpubpol.2009.06.006

Harrison, J. R. (1987). The strategic use of corporate board committees. California Management Review, 30(1), 109-125. http://dx.doi.org/10.2307/41165269

Hoyt, R. E., \& Liebenberg, A. P. (2011). The Value of Enterprise Risk Management. Journal of Risk and Insurance, 78(4), 795-822. doi:10.1111/j.1539-6975.2011.01413.

Jensen, M. C., \& Meckling, W. H. (1976). Theory of the firm: Managerial behavior, agency costs and ownership structure. Journal of Financial Economics, 3(4), 305-360.

Kallamu, B. S., (2015). Risk Management Committee Attributes and Firm Performance. International Finance and Banking Vol. 2, No. 2, ISSN 2374-2089

Kaplan, R. S., Colica, J. A., Ranganath, M. D., \& Zubrow, B. L. (2008). Entreprise risk management. Harvard Business Scholl The Centennial Global Bussines Summit Report 2008.

Kashyap, A., Rajan, R., \& Stein, J. (2008). Rethinking capital regulation. [Online] Available: http://scholar.harvard.edu/sites/scholar.iq.harvard.edu/files/stein/files/kashyaprajanstein.03.12.09.pdf

Koran SINDO. (2016). Bankruptcy firms in di Indonesia. Retrieved from http://ekbis.sindonews.com/read/1085897/39/perusahaan-besar-bangkrut-di-indonesia-1455640928 
KPMG (2001), Enterprise Risk Management: An Emerging Model for Building Shareholder Value, KPMG.

KPMG (2005), Strategic Risk Management Survey: A Survey of Contemporary Strategic Risk Management Practices in Australia and New Zealand, KPMG.

Krause, A. (2006). Risk, capital requirements, and the asset structure of companies. Managerial Finance, 32, $774-85$. http://dx.doi.org/10.1108/03074350610681961

Machek O. (2016), Comparative performance of foreign and domestic family firms in Czech Republic, Journal of International Studies, Vol. 9, No 1, pp. 205-218. DOI: 10.14254/2071-8330.2016/9-1/15

Ng, T-H., Chong, L-L., \& Ismail, H. (2013). Is risk management committee only a procedural compliance? An insight into managing risk taking among insurance companies in Malaysia. The Journal of Risk Finance, 14(1), 71-86. http://dx.doi.org/10.1108/15265941311288112

Porter, B. A., \& Gendall, P. J. (1998). Audit Committees in Private and Public Sector Corporates in New Zealand: An Empirical Investigation. International Journal of Auditing, 2(1), 49.

Raghunandan, K., \& Rama, D. V. (2007). Determinants of audit committee diligence. Accounting Horizons, 21(3), 265279.

Saedi, P., Sofian, S., Zaleha, S. (2014). A Proposed model of the relationship between enterprise risk management and firm performance. International Journal of Information Processing and Management (IJIPM), 5 (2), 70-80.

Sambera, G. F., \& Meiranto, W. (2013). Analysis of board characteristics and firm characteristics on the establishment of risk management committee. Diponegoro Kournal of Accounting 2(3), 1-14.

Subramaniam, N., McManus, L., \& Zhang, J. (2009). Corporate governance, firm characteristics and risk management committee formation in Australian companies. Managerial Auditing Journal, 24(4), 316-339.

Viljoen, P.H.; Coetsee, D, Prof. (2014). The relationship between entity related corporate governance factors and the establishment of separate risk management committee in South Africa. Dissertation in University of Johannesburg http://hdl.handle.net/10210/11132

Yasser, Q. R., Entebang, H., \& Mansor, S.A. (2011). Corporate governance and firm performance in Pakistan: The case of Karachi Stock Exchange (KSE)-30, Journal of Economics and International Finance, 3(8), 482-491.

Yatim, P. (2009). Audit committee characteristics and risk management of Malaysian listed Firms. Malaysian Accounting Review, 8(1), 19-36.

Yatim, P. (2010). Board Structures and the Establishment of A Risk Management Committee by Malaysian Listed Firms. Journal of Management and Governance, 14 (1),17-36.

Zemzem A.\& Kacem O. (2014) . Risk Management, Board Characteristics and Performance in the Tunisian Lending Institutions International Journal of Finance \& Banking Studies Vol 3, No 1. ISSN: 2147-4486 